\title{
A Historical Study of the Influences of European Immigration on the Formation of American English
}

\author{
Chunming Gao \\ School of Foreign Languages, Changchun University of Science and Technology, Changchun, China \\ Lili Sun \\ School of Foreign Languages, Changchun University of Science and Technology, Changchun, China
}

\begin{abstract}
The paper studies the formation of American English under the influence of European immigration from a historical perspective. A literature review is presented first with many important early researches on American English, the history of American English, and American immigration. Then a general survey of American English is put forward, including how American English is defined, what the typical features are, how American English is formed and developed. The focus of the paper is the influences of European immigration on the formation of American English, in which the influences of Spanish, French, Dutch and German immigration are illustrated respectively.
\end{abstract}

Index Terms - American English, European immigration, historical perspective

\section{INTRODUCTION}

Language is an important carrier of a country's national culture and is also inevitably affected by the culture. With the development of the world, the global pattern changes quickly and American culture is affecting the world in various forms. It gains great academic and practical significance to study the formation and development of American English under the influence of American immigration culture, which helps understand the history of American English, American culture and American values.

Although the researches on American English are quite rich, they are very limited on the issue of the influence of European immigration on American English. This paper studies the formation of American English under the influences of European immigration culture to better reveal that history, culture and language are intercommunicating all the time, and that people may better know the history and development of American English and deepen their understanding of American culture and American values.

\section{LITERATURE REVIEW}

To get a general idea of the previous research of American English, the authors refer to China National Knowledge Infrastructure which is the biggest online platform for academic articles in China. Key words "American English", "British English" and "American immigration culture" had been retrieved in the database. It can be seen that the study of American English from the perspective of linguistics and literature has been paid more attention but few articles have been published concerning the study of American English from the perspective of history and culture. In this sense, the formation and development of American English under the influence of American immigration culture is a subject requiring more research efforts.

\section{A. Previous Research in China}

The first true masterpiece of American immigration history in China undoubtedly belongs to Deng Shusheng' with his America and Immigration-History, Present and the Future. Afterwards Huang Zhaoqun's Diverse American Society: American Nation and Its National Culture (1994) explores the history and culture of various ethnic groups in the United States in detail and reviews the evolution of American society from cultural perspective. Scholar Lai Anfang (2004) elaborately introduces the politics, economy, culture and history in An Outline Introduction to Britain and America, which is very helpful for the study of the impact of immigration culture on American English. In The History of English, Li Funing (1991) divides the historical process stages of American English in his own way and discusses the impact of the American immigration culture on American English from a historical perspective. However, in this regard, Li does not deepen the study on American English from the immigration culture perspective.

In American English and American Culture, Wang Zongyan, Zheng Lixin and Gu Jiazu (1993) combine history, culture and language study together, exploring the formation and development of American English, introducing various regional variants of American English in detail and putting language study onto the stage of intercultural communication. 
It is in very vivid language with great academic and practical significance. English and the World by Niu Daosheng (2008) published by Social Sciences Press in China in 2008 explores the development of English around the whole world and describes the distribution of English, and focuses on the development of British English and American English.

Related academic articles are also seen in journals, such as Liu Songxin's "On American Early Immigration Culture" published in the Economist in 2010. In "The Differences on Vocabulary Between American English and British English" published in Crazy English in 2011, Cai Xiaohui and Min Zuchuan describe many differences between American English and British English. The differences on vocabulary mainly lie in nouns, verbs and so on. A large number of research papers also emerge, such as Li Yanwei's "The Formation of American English and American History" published in Journal of Tianjin University (Social Sciences Edition) in 2001, Dai Weiping and Gao Weigui's "American English and American Culture" published in Sichuan International Studies University in 2001 and Shan Wenbo's "The Origin and Developing Trend of American English" published in Adult Education College of Hubei University in 2005. These papers explore American English and American immigration culture from either linguistic or cultural perspective, but they are not deep enough. To sum up, although the researches on American English and American immigration culture are very rich, the study on the formation and development of American English under the influence of American immigration culture is still rare.

\section{B. Previous Research Outside of China}

The study on American English has received a lot of concern in recent years. There is much work investigating it from different angles. It is well known that the research on English is undertaken by professionals in English linguistics and literature. As one variant of English, the research on American English naturally follows two pathways-linguistics and literature. Scholars of American literature tend to study American English through the style and skills of using language while linguistics experts analyze American English from linguistic point of view, i.e., pronunciation, vocabulary and grammar. H. L. Mencken (1977) contributes a masterpiece in linguistics-American Language which was published by Alfred A. Knopfe, Inc. in 1977. It explains the origin of American slang, geographical names and the impact of foreign language on American English. Robert Burchfield (1992), the writer of The English Language, gives a brief survey of the development of English and describes the various changes of the language through the $18^{\text {th }}$ century, right up to the enormous changes in the English language that have taken place in the $20^{\text {th }}$ century and the changes over the years into its modern form.

Since the 20th century, Garland, Cannon and R. W. Burchfield find another way to study American English-to trace the history of American English from the perspective of human civilization and define the development process of American English in historical method. (Li, 2001) J. L. Dillard's (1992) A History of American English published in 1992 provides for the first time a description of the development of American English from a historical perspective. Dillard tracks the development of American English from its earliest origins to the present day and analyzes a variety of forms of American English, such as "standard", Black and pidgin. It writes about the influences of maritime contacts, the Negro, Dutch, Hawaiian, Spanish, French, Italian and German on the development of American English.

One of the best works of foreign academic study on American immigration history is The Uprooted written by American historian Oscar Handlin (1951) in the 20th century. This book specifically and vividly tells about the suffering time of 18th century European immigrants who came to America across the oceans to achieve their American dream. The first sentence of the book - "When I wanted to write a book about the history of American immigration, I found that the history of American immigration is the history of America", makes a judgment of the relationship between American history and American immigration, and reveals the influence of American immigration culture on American English. Maldwyn Allen Jones (1992) analyzes the forces and adjustments of the uprooted emigrants in different parts of the world who made it to America to achieve their American dreams in American Immigration which was published by University of Chicago Press in 1992. He describes the role which they play in industrialization, the westward movement, labor organization, the growth of American nationalism, and the practice of democracy.

\section{GENERAL SURVEY OF AMERICAN ENGLISH}

\section{A. The Definition of American English}

American English is a form of English used in the United States. It is the major language used in the United States. According to the 1990 census, $97 \%$ of U.S. residents use English well or very well and only $0.8 \%$ of people do not speak English. By 2005, more than two thirds of native speakers of English speak American English. American English standardizes the first-generation English (British English), becoming the second-generation English in history of modern English. American English and British English form the foundation of the third-generation English (World English). (Mingyuzhixing, 2014)

The proposal of "American English" was not very easy. In the early colonial period, English used in the United States was called "North American English" (English in North America) or "colonial English". The second period was around 1920s, Columbia University professor George P. Krapp advocated that the national language should be collectively referred to as "The English Language in America". In the third period, William Craigie and James R. Hulber used the name "American English" for the first time in their dictionary Dictionary of American English (1938-1944), but the final formation of "American English" was finished by Noah Webster. Thus, "American English" is not a separate 
language; it's a variant of British English.

From 1607, the British in the American colonies established the first colony in Virginia. Jamestown is established and the British colonists brought Shakespeare and Milton English to America, known as English in North America or Colonial English. So American English is a regional English variant in the process of British rule in North America. American English is the national language of the United States which is improved and standardized with America's independence and territorial expansion. With the rising international status of the United States as a superpower, American English becomes more and more dominant in the development of English around the whole world.

American English is not an independent language. It is a regional language variant of British English, which originates from British English in the17-18 century and stands on its own today in this particular geographical environment-North America.

\section{B. The Typical Features of American English}

American English is a regional language variant of British English, which originated in the 17-18 century British English. It is formed in this particular geographical environment-North America, by the impact of social and cultural diversity and innovation. Some characteristics in American English make it different from British English which are listed.

(1) Inclusiveness

America is a nation of immigration and the language of America has improved into contemporary American English with the absorption of the essence of other nations, such as French, Dutch, Spanish and German. For example, prairie from French; canyon from Spanish; hamburger from German.

(2) Flexibility

American English is very flexible. It often takes new forms or contents to meet the needs in reality. For example, some words are changed into different forms with different meanings such as brunch, black sheep, white collar.

(3) Conservatism

Some American words still keep the traditional using of early English while modern British English has dropped away such as fall in American English and it shares the same meaning with autumn. Some old words are still in use in American English while in British English they have been out of usage, such as cordwood.

In pronunciation, contemporary American English still keeps several features of Elizabethan English, and these features have ceased to exist in contemporary British English, such as [æ] pronounced in the word last in Elizabethan English. It still exists in American English.

(4) Innovation

As is well known American people are full of creativity and courage. With the social development a lot of new words and new forms spring up in American English such as test-tube baby in medicine and soup opera in media. And some other words are created in American English such as black hole, smog.

\section{The Formation and Development of American English}

American English is a regional variant of British English, which originated in the 17-18 century British English. Its history is closely related with the history of British English. The first Indo-inhabitant of the British Isles was the Celts. In the fifth century, the Angles and Saxon occupied England and Celts retreated to the Wales, Ireland and Scottish Highlands. The word "English" came from "Angles", meaning "corner". "Angle" in Old English was written as "Engle" and the language was called "Englisc". The "sc" in Old English was read as the pronunciation of "sh". That is where the pronunciation of the word "English" came from.

After Columbus discovered the New World-America, Spain, France, Netherlands, Britain and other powers went to America. Britain ultimately became the Queen of the Seas with its powerful military force. In 1607, a group of British sent by the British London Company landed on the mouth of James River, and established Jamestown. Later, the British established the first colony in North America-Virginia colony, which marked the British settlement in North America for the first time and the British language and culture began to spread in the North America. In 1620, another group of British took the ship of "Mayflower" to immigrate to North America. Because of the storm, they landed on the Plymouth and settled down. They brought the Elizabethan English to North America, which became the origin of American English. From 1607 when the first colony established by Britain in North America to 1733, the British established a total of 13 colonies along the Atlantic coast of North America and English became the universal language in British colonies. These British immigrants belonged to middle and lower class. The language they used was the origin of American English.

Since then, in the United Kingdom and North America, the Elizabethan English began to develop in two different ways. With the different socio-cultural and geographical environment, gradually the differences in pronunciation, vocabulary, grammar and even spelling came up between the British English and American English. In a certain sense, it is North America's diverse immigration culture that created the American English.

In the early British colonial period, these immigrants kept close contact with their home town and their language shared the same changes with British English. As time went by, in North America, a new kind of English came up different from British English. And the American Independence War was a historical turning point indicating the emergence of American English. Benjamin Franklin published an article, in which he tried to change spelling of words, such as honor to replace honour. His theory had a huge impact on the vocabulary scientist and lexicographer Noah Webster. He wrote 
American Dictionary of English Language in 1828. He systematically and comprehensively fixed down the meaning and form of American English, laying a solid foundation for the future development of American English. American English ever since has a dictionary of its own. It marks the formation of American English as an independent language.

\section{THE INFLUENCES OF EUROPEAN IMMIGRATION ON AMERICAN ENGLISH}

In terms of immigrants to the United States, the melting pot process has been the process of Americanization, that is, cultural assimilation and acculturation. In the late 19th and early 20th centuries, European immigration to the United States became increasingly diverse and increased substantially in number. In the early 1890s, large numbers of Southern and Eastern European immigrant groups such as the Italians, Jews, and Poles arrived. Many returned to Europe but those who remained merged into the cultural melting pot, adopting American lifestyles.

In the early 20th century, the meaning of the recently popularized concept of the melting pot was subject to a debate which centered on how immigration impacted American society and on how immigrants should be treated. However, race melting enriches the nation's culture. Different races with different cultures come to this country continually, in this new nation. All these different elements interact with each other, and form the unique American culture. It also explains why there are so many loan words in American English. American English like the nation itself is diverse, and absorbs many language elements from different languages. The following is about the influences on American English from the perspectives of Spanish, French, Dutch, and German immigration.

\section{A. The Influence of Spanish on American English}

It is over 200 years for Spanish colonial rule in North America, especially in the southwest of North America. After America was independent from the Britain, gradually it occupied this region in the process of territorial expansion and Westward Movement. Since then, American English and Spanish keep interacting with each other in this region. According to historical records, before going to North America, the British already shared culture and business with other European languages, which of course included Spanish borrowing. After British immigration came to North America, these borrowed words were still in use in the North American colonies, which had great impact on American English. Especially after the Mexican War and the California Gold Rush, Spanish penetrated into almost every areas of social life in the United States.

Historically, since the 1820 s, large numbers of immigrants of the United States came to Texas region which was the territory of Mexico at the time, and later these U.S. immigrants planned insurgency in the region, declaring the independence of Texas from Mexico. In 1846, Mexican-American War broke out and Mexico was forced to cede large areas of territory to the United States.

As the carrier of national culture, American English and Spanish share some similarities with each other. Because of its own characteristics - strong local characteristics, rich language content and a sense of humor, a large number of Spanish words were introduced into American English. For example, food, mescal, tortilla; clothes, poncho, sombrero; and others like mosquito, cafeteria, canyon, cinch. These borrowed words from Spanish are closely related to the social life in that period.

\section{B. The Influence of French on American English}

As we all know, from a historical point of view, French has a significant impact on English. First of all, French and English belong to the Indo-European language family. In 1526, the first group of French settlers came to North America, which marked the beginning of French immigration history to North America. In fact, since the Norman Conquest, a large number of French words were introduced into English, becoming a part of English etymology. In 1731, New Orleans and Louisiana region became French colonies. In the 17th century, a large number of French immigrated to this area, and French culture had a great effect on this region. These people brought the French diet, art and culture to the North American continent and French vocabulary began to have an impact on American English. In 1803, Napoleon came to power and launched wars everywhere, which made the shortage of funds. The United States only spent \$15 million for the purchase of large tracts of land of the Mississippi River region from France including Louisiana. Since then, American English and French influenced each other increasingly.

During the colonial period, American English mainly directly borrowed French vocabulary. At the early time, France occupied many colonies in North America and many daily necessities were named in French. After these colonies were occupied by the United States, some French words were borrowed directly and absorbed into American English. In the early American English, the words borrowed from French were taxi, pumpkin, portage. After the War of Independence, because of great assistance to the United States, the French-American relations became harmonious and a lot of vocabulary about French cooking, art, music, literature, fashion and other aspects were introduced into American English such as caffe latte, dinner, pork and banquette. Also French slang was introduced into American English such as chisel.

\section{The Influence of Dutch on American English}

Dutch influence on American English is huge. Historically, the Dutch colonists gained great power in North America, and later many Dutch settled down in North America. In the 17th century, the Dutch maritime industry was very developed and played an in important role in international trade. Inevitably many Dutch words came into American 
English. In 1609, Dutch explorer Henry Hudson came to North America. In 1621, with a value of \$ 24 commodities the Netherlands purchased the ownership of the island of Manhattan from the Indians, where it established the first colony named New Amsterdam, and later established the colony of New Netherland. Today, New York's Broadway is from the Dutch name Bredweg. There are many words in American English which are borrowed from Dutch such as luck, cookie, dollar, boss and go Dutch. And the expression in American English "How come?" is also from the Dutch "hoekom".

\section{The Influence of German on American English}

In 1683, thirteen families established the first permanent settlement in Pennsylvania, which marked the beginning of German immigration to North America. Germany's traditional culture kept constant contact with American English culture and had profound impact on American English. From the beginning of the 18th century, German was the largest number of foreign immigrants in the United States. German immigrants in the United States promoted a variety of activities, such as picnics, music, etc., and brought German beer and sausage production to the United States. Germany's culture brought by the immigrants penetrated into American culture and the world-famous Germany hamburger, alcoholic beverages and sausage became a part of American life.

In American English, the borrowed words from German are mainly related with food and drinking such as hamburger, noodle and beer soup. And other words and expressions from German are also in large number like semester, seminar, and kindergarten.

\section{CONClusion}

America is a nation of immigrants and immigration culture has had a profound impact on the development of American English. The English is the major wave of immigration in colonial period, followed by the Irish, German, and later a large number of black Africans who were traded to North America as slaves. After the Civil War, a number of immigrants from other European countries came to North America.

Language is an important carrier of a country's national culture and also inevitably affected by the culture. In a certain sense, it is North America's diverse immigration culture that created the American English. It is very necessary to study the influence of American immigration culture on American English. Among these immigration culture, European immigration played the biggest role.

\section{REFERENCES}

[1] Burchfield, R. W. (1992). The English Language. Beijing: Foreign Language Teaching and Research Press.

[2] Cai, Xiaohui, Min, Zuchuan. (2011). The Differences on Vocabulary Between American English and British English. Crazy English. 04: 152-155.

[3] Dillard, J. L. (1992). A history of American English. London: Longman.

[4] Handlin, Oscar. (1951). The Uprooted: The Epic Story of The Great Migrations That Made The American People, New York: Crosset and Dunlap Publishers, Inc.

[5] Huang, Zhaoqun. (1994). Diverse American Society: American Nation and Its National Culture. Inner Mongolia: Inner Mongolia University Press.

[6] Jones, Maldwyn Allen. (1992). American Immigration. Chicago: University of Chicago Press.

[7] Lai, Anfang. (2004). An Outline Introduction to Britain and America. Zhengzhou: Henan People's Press.

[8] Li, Funing. (1991). The History of English. Beijing: The Commercial Press.

[9] Li, Yan. (2008). The Histroy and Features of American English. Science Technology. 01: 96-98.

[10] Li, Yanwei. (2001). The Formation of American English and American History. Journal of Tianjin University. 03: $262-265$.

[11] Mencken, H.L. (1977). American Language. New York: Alfred A. Knopfe, Inc.

[12] Mingyuzhixing. (2014). http://baike.baidu.com/view/100877.htm, Retrieved 2014-05-21.

[13] Niu, Daosheng. (2008). English and the World. Beijing: Social Sciences Press in China.

[14] Wang, Zongyan, Zheng, Lixin, \& Gu, Jiazu. (1993). American English and American Culture. Changsha: Hunan Education Press.

Chunming Gao was born in 1979 in Jilin Province, China. She received her M.A degree in Linguistics and Applied Linguistics in Foreign Languages from Changchun University of Science and Technology in 2006 and then began to work there as a lecturer. Her major research interests include applied linguistics and cross-cultural communication.

Lili Sun is a graduate of the English Department in the School of Foreign Languages, Changchun University of Science and Technology, China in the year of 2014. 